International Journal of Current Microbiology and Applied Sciences

ISSN: 2319-7706 Volume 6 Number 8 (2017) pp. 477-480

Journal homepage: http://www.ijcmas.com

Original Research Article

https://doi.org/10.20546/ijcmas.2017.608.062

\title{
Evaluation of Bio-Efficacy and Phytotoxicity of Difenconazole 25\% EC against Die Back, Fruit Rot and Powdery Mildew Diseases of Chilli
}

\author{
M. Abdul Kareem*, Krishna D. Kurubetta, P.S. Ajjappalavara, M.H. Tatagar, \\ K. Shweta, Dileepkumar Masuthi and M.A. Waseem
}

Horticulture Research and Extension Station, Devihosur, Haveri - 581 110, Karnataka, India *Corresponding author

A B S T R A C T

\begin{tabular}{|l|}
\hline Ke y w or d s \\
Chilli, die back, \\
fruit rot and \\
powdery mildew, \\
difenconazole, \\
field evaluation. \\
\hline Article Info \\
\hline Accepted: \\
04 June 2017 \\
Available Online: \\
10 August 2017 \\
\hline \hline
\end{tabular}

A field study has been conducted at Horticulture Research and Extension Station, Devihosur on the management of die back, fruit rot and powdery mildew using different concentrations of Difenconazole 25\% EC (Willowood Chemicals Pvt. Ltd). Difenconazole @ $0.07 \%$ and $0.1 \%$ recorded significantly least PDI compared to all other treatments. Yield was significantly highest in Difenconazole@0.1\% (7.35 q/ha) than all the treatments and was on par with Difenconazole @ $0.07 \%(7.27 \mathrm{q} / \mathrm{ha}) \&$ Difenconazole 25 EC @ 0.05\% (7.02 q/ha). No phytotoxicity symptoms were observed at all stages of crop growth by the application of Difenconazole.

\section{Introduction}

Chilli (Capsicum annuum) is an important crop grown worldwide for its use as spices and vegetables. It is an indispensable spice used as basic ingredient in a great variety of cuisines all over the world. Chilli belongs to Capsicum $(2 \mathrm{n}=24)$ a new world genus belonging to Solanaceae family. It is an excellent source of vitamin $\mathrm{C}, \mathrm{A}, \mathrm{B}$-complex and $\mathrm{E}$. It contains seven times more vitamin $\mathrm{C}$ than orange. India is the largest producer of chilli crop, grown over an area of 0.794 million hectares with an annual production of 0.13 million tonnes with the productivity of 1.5 tonnes/ha (Anonymous, 2014). The important states growing chilli are Andhra Pradesh, Karnataka, Orissa, Maharashtra,
West Bengal, Rajasthan and Tamil Nadu. Karnataka ranks second in area with 100.73 ('000 ha) and production 107.00 ('000 MT) of dry chilli after Andhra Pradesh (Anonymous, 2014). In Karnataka, northern Karnataka is an important chilli growing area and it is highly concentrated in the districts like Dharwad, Haveri, Koppal, Ballari, Raichur, Kalaburagi and Belagavi.

\section{Materials and Methods}

An experiment was conducted at Horticulture Research and Extension Station, Devihosur, Haveri to study the efficacy and phytotoxicity of difenconazole 25\% EC against die back, 
fruit rot and powdery mildew diseases of chilli. It was conducted in randomized block design with three replications under field conditions during Kharif 2013-14. Seedlings of chilli cv. Byadgi Dabbi were planted in the plot $(4.8 \mathrm{~m} \times 3.6 \mathrm{~m})$ with a spacing of $0.6 \mathrm{~m} \mathrm{x}$ $0.6 \mathrm{~m}$. First spray was given immediately after a first symptom of disease was observed. Remaining two sprays were given at 15 days interval. Control was maintained with no fungicidal spray. The severity of the disease was measured using 0-9 disease rating scale given by Mayee and Datar (1986).

\begin{tabular}{|c|c|}
\hline Grade & $\begin{array}{c}\text { Per cent } \\
\text { Infection }\end{array}$ \\
\hline 0 & $0 \%$ \\
\hline 1 & $1-10 \%$ \\
\hline 3 & $11-25 \%$ \\
\hline 5 & $26-50 \%$ \\
\hline 7 & $51-75 \%$ \\
\hline 9 & $>75 \%$ \\
\hline
\end{tabular}

\section{Results and Discussion}

The effect of difenconazole $25 \%$ EC on the die back, powdery mildew, fruit rot and yield of chilli presented in tables 1 and 2 respectively.

\section{Bioefficacy of difenconazole $25 \%$ EC against die back of chilli}

The severity of die back differed significantly with respect to all the treatments at all stages of observation. The per cent disease index recorded on die back of chilli revealed that difenconazole 25\% EC @ 0.07\% and 0.1\% recorded significantly least percent disease index of dieback (6.66 and 5.92 PDI respectively) compared to other treatments but on par with difenconazole 25\% EC @ $0.05 \%$ (7.40 PDI). The untreated control (30.34 PDI) recorded significantly highest percent disease index of dieback.
Bioefficacy of difenconazole $25 \% \quad$ EC against fruit rot of chilli

The treatments differed significantly with respect to the severity of fruit rot. Fruit rot severity was significantly least in difenconazole 25\% EC @ 0.1\% (24.33 PDI) followed by difenconazole 25\% EC @ 0.07\% (25.90 PDI). These two treatments were on par with each other along with difenconazole 25\% EC @ $0.05 \%$ (28.29 PDI), but significantly superior over the other treatments. The untreated control (68.27 PDI) recorded significantly highest percent disease index. Gopinath et al., (2006) reported that application of propiconazole at $0.1 \%$ caused a dramatic reduction of anthracnose disease incidence by $70 \%$ followed by difenoconazole at $0.05 \%(58 \%)$ and carbendazim at $0.1 \%$ (44\%).

Bioefficacy of difenconazole $25 \%$ EC against powdery mildew of chilli

The treatments differed significantly with respect to the severity of powdery mildew. Powdery mildew severity was significantly least in treatments with difenconazole $25 \%$ EC@ $0.07 \%$ and $0.1 \%$ (26.88 and 26.64 PDI respectively) but on par with difenconazole 25\% EC@0.05\% (28.62 PDI). The untreated control (57.33 PDI) recorded significantly highest percent disease index.

\section{Yield}

The treatments differed significantly with respect to yield of dry chilli. Difenconazole 25\% EC @ 0.1\% (7.35 q/ha) recorded significantly highest yield than all the treatments and was on par with difenconazole $25 \% \quad$ EC @ $0.07 \% \quad(7.27$ q/ha $)$ and difenconazole 25\% EC @ 0.05\% (7.02 q/ha). SCORE 25 EC (Difenconazole 25 EC) @ $0.05 \%$ (6.69 q/ha) and difenconazole 25\% EC @ $0.025 \%$ (6.06 q/ha) were next in order. 
Table.1 Effect of difenconazole 25\% EC on die back, fruit rot and powdery mildew diseases of chilli

\begin{tabular}{|c|c|c|c|c|c|}
\hline Sl. No. & Treatments & $\begin{array}{c}\text { Formulation } \\
\text { Dosage }\end{array}$ & $\begin{array}{l}\text { Die Back } \\
\text { (PDI) }\end{array}$ & $\begin{array}{l}\text { Fruit rot } \\
\text { (PDI) }\end{array}$ & $\begin{array}{c}\text { Powdery } \\
\text { mildew } \\
\text { (PDI) }\end{array}$ \\
\hline 1 & Difenconazloe $25 \%$ EC & $0.025 \%$ & $\begin{array}{c}12.58 \\
(24.61) *\end{array}$ & $\begin{array}{c}56.98 \\
(49.01) *\end{array}$ & $\begin{array}{c}40.33 \\
(28.01) *\end{array}$ \\
\hline 2 & Difenconazloe $25 \%$ EC & $0.05 \%$ & $\begin{array}{c}7.4 \\
(19.45) *\end{array}$ & $\begin{array}{c}28.29 \\
(32.13) *\end{array}$ & $\begin{array}{c}28.62 \\
(24.41) *\end{array}$ \\
\hline 3 & Difenconazloe $25 \%$ EC & $0.07 \%$ & $\begin{array}{c}6.66 \\
(18.35) *\end{array}$ & $\begin{array}{c}25.90 \\
(30.59) *\end{array}$ & $\begin{array}{c}26.88 \\
(24.03) *\end{array}$ \\
\hline 4 & Difenconazloe $25 \%$ EC & $0.1 \%$ & $\begin{array}{c}5.92 \\
(18.35) *\end{array}$ & $\begin{array}{c}24.33 \\
(29.56) *\end{array}$ & $\begin{array}{c}26.64 \\
(24.03) *\end{array}$ \\
\hline 5 & $\begin{array}{l}\text { SCORE } 25 \text { EC } \\
\text { (Difenconazloe } 25 \% \text { EC) }\end{array}$ & $0.05 \%$ & $\begin{array}{c}10.36 \\
(23.41) *\end{array}$ & $\begin{array}{c}34.78 \\
(36.14) *\end{array}$ & $\begin{array}{c}36.10 \\
(27.37) *\end{array}$ \\
\hline 6 & Carbendazim 50\% WP & $0.1 \%$ & $\begin{array}{c}12.58 \\
(25.66) *\end{array}$ & $\begin{array}{c}59.31 \\
(50.37) *\end{array}$ & $\begin{array}{c}43.33 \\
(29.28) *\end{array}$ \\
\hline 7 & Control & - & $\begin{array}{c}30.34 \\
(28.14) *\end{array}$ & $\begin{array}{c}68.27 \\
(55.72) *\end{array}$ & $\begin{array}{c}57.33 \\
(29.95) *\end{array}$ \\
\hline \multicolumn{2}{|r|}{$\mathrm{CD}$ at $5 \%$} & - & 8.53 & 2.63 & 7.45 \\
\hline
\end{tabular}

* Figures in parenthesis are angular transformed values

Table.2 Effect of Difenconazole 25\% EC on yield of dry chilli

\begin{tabular}{|c|l|c|c|c|}
\hline \multirow{2}{*}{ Sl. No. } & \multicolumn{1}{|c|}{ Treatments } & \multicolumn{3}{c|}{ Dry yield (q/ha) } \\
\cline { 3 - 5 } & \multicolumn{1}{|c|}{} & $\begin{array}{c}\text { Yield } \\
(\mathbf{q} / \mathbf{h a})\end{array}$ & $\begin{array}{c}\text { Percent increase } \\
\text { in yield over } \\
\text { control } \\
(\%)\end{array}$ & $\begin{array}{c}\text { Percent increase } \\
\text { in yield over } \\
\text { Standard Check } \\
\text { (Score 25 EC) } \\
\text { (\%) }\end{array}$ \\
\hline 1 & Difenconazloe 25\% EC @ 0.025\% & 6.06 & 51.50 & - \\
\hline 2 & Difenconazloe 25\% EC @ 0.05\% & 7.02 & 75.50 & 4.9 \\
\hline 3 & Difenconazloe 25\% EC @ 0.07\% & 7.27 & 81.75 & 8.6 \\
\hline 4 & Difenconazloe 25\% EC @ 0.1\% & 7.35 & 83.75 & 9.8 \\
\hline 5 & $\begin{array}{l}\text { SCORE } \\
\text { (Difenconazloe 25\% EC) @ 0.05\% }\end{array}$ & 6.69 & 67.25 & - \\
\hline 6 & Carbendazim 50\% WP @ 0.1\% & 5.17 & 29.25 & - \\
\hline 7 & Control & 4.00 & - & - \\
\hline & \multicolumn{1}{c}{ CD at 5\% } & 0.38 & & \\
\hline
\end{tabular}

The untreated control (4.00 q/ha) recorded significantly least yield (Table 2).

Difenconazole 25\% EC @ 0.1\% recorded an increased yield of $83.75 \%$ over control as well as $9.8 \%$ against standard check (Score 25 EC) and was on par with difenconazole $25 \%$ EC @ $0.07 \% \quad(81.75 \%$ and $8.6 \%)$ and difenconazole 25\% EC @ 0.05\% (75.50\% and 4.9\%). Gopinath et al., (2006) reported that 
fruit yield increased in the range of $86 \%, 63 \%$ and $60 \%$ for propiconazole, difenoconazole and carbendazim, respectively, when compared to unsprayed controls.

\section{Phytotoxicity}

No phytotoxicity symptoms were observed at all stages of crop growth by the application of the test chemical Difenconazole 25\% EC of any concentration at $0,3,7$ and 15 days after each application.

\section{References}

Anonymous. 2014. Directorate of economics and statistics, New Delhi.

Gopinatha, K., Radhakrishnana, N.V. and Jayaraja, B.J. 2006. Effect of propiconazole and difenoconazole on the control of anthracnose of chilli fruits caused by Colletotrichum capsici. Crop Protection, 25(9): 1024-1031.

Mayee, C.D. and Datar, V.V. 1986. Phytopathometry Technical Bulletin-1 (Special Bulletin-3), Marathwada Agricultural University, Parbhani.

\section{How to cite this article:}

Abdul Kareem, M., Krishna D. Kurubetta, P.S. Ajjappalavara, M.H. Tatagar, K. Shweta, Dileepkumar Masuthi and Waseem, M.A. 2017. Evaluation of Bio-Efficacy and Phytotoxicity of Difenconazole 25\% EC against Die Back, Fruit Rot and Powdery Mildew Diseases of Chilli. Int.J.Curr.Microbiol.App.Sci. 6(8): 477-480. doi: https://doi.org/10.20546/ijcmas.2017.608.062 